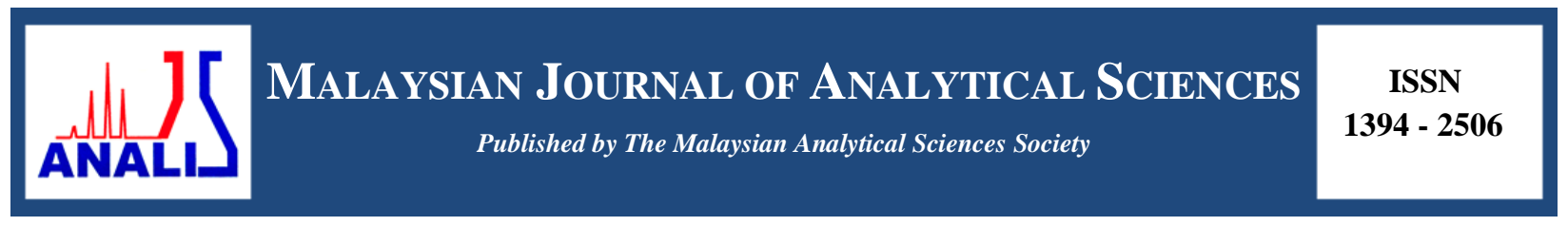

\title{
PHYTOCHEMICAL STUDY ON THE STEM BARK OF Mallotus leucodermis Hook F.
}

\author{
(Kajian Fitokimia ke atas Kulit Ranting Mallotus leucodermis Hook F.) \\ Aiza Syuhada Mohd Yusoff ${ }^{1}$, Norizan Ahmat ${ }^{1,2}$, Humera Naz $^{2}$ \\ ${ }^{1}$ Department of Chemistry, Faculty of Applied Sciences, \\ Universiti Teknologi MARA, 40450 Shah Alam, Selangor, Malaysia \\ ${ }^{2}$ Atta ur Rahman Institute for Natural Products Discovery, \\ Universiti Teknologi MARA, 42300 Bandar Puncak Alam, Selangor, Malaysia \\ *Corresponding author: noriz118@salam.uitm.edu.my
}

Received: 24 February 2015; Accepted: 27 October 2015

\begin{abstract}
The stem barks of Mallotus leucodermis Hook F. (Euphorbiaceae) was studied for its chemical constituents. The air dried and pulverized of stem bark of $M$. leucodermis $(1.3 \mathrm{~kg}$ ) was extracted successively with acetone for three days at room temperature yielding $66.0 \mathrm{~g}$ of crude extract. The crude extract was fractionated using vacuum liquid chromatography (VLC) to afford six fractions. Fraction 6 was further washed and recrystallized to afford bergenin (1). Fraction 3 was subjected to multiple purification using radial chromatography $\left(\mathrm{CHCl}_{3}\right.$ : acetone) with different ratio 9:1, 8:2, 6:4 and 5:5 to yield a flavonoid compound, epicatechin (2). These compounds were elucidated based on spectroscopic analysis (Ultra Violate, Infra-Red, Mass Spectrometry and Nuclear Magnetic Resonance) as well as comparison with literatures.
\end{abstract}

Keywords: Euphorbiaceae, Mallotus, bergenin, epicatechin

\begin{abstract}
Abstrak
Kulit ranting Mallotus leucodermis Hook F. (Euphorbicaeae) telah dikaji untuk sebatian kimianya. Kulit ranting M. leucodermis $(1.3 \mathrm{~kg})$ yang telah dikeringkan dan dikisar, direndamkan dalam aseton selama tiga hari pada suhu bilik bagi memperolehi $66.0 \mathrm{~g}$ bahan ekstrak. Fraksinasi telah dilakukan ke atas ekstrak tersebut dgn menggunakan hampagas kromatografi cecair dan menghasilkan enam fraksi. Fraksi 6 telah dicuci beberapa kali dan dihablurkan semula untuk menghasilkan bergenin (1). Manakala fraksi 3 ditulenkan beberapa kali menggunakan radial kromatografi untuk mendapatkan sebatian flavonoid, epicatechin (2). Dua sebatian tulen ini dikenal pasti berdasarkan analisis spektroskopi (Ultralembayung, Inframerah, Spektrometri Jisim and Resonans Magnet Nukleus) dan juga perbandingan data.
\end{abstract}

Kata kunci: Euphorbiaceae, Mallotus, bergenin, epicatechin

\section{Introduction}

Mallotus leucodermis Hook F., is a species under genus of Mallotus from Euphorbiaceae family. Euphorbiaceae is also commonly known as spurge family. The family of Euphorbiaceae consists of 283 genera and 7300 species which have been distributed in tropical region around the world. The main genus of Eurphobiaceae family consist of Euphorbia, Phyllantus, Mallotus, Macaranga and many more [1]. Mallotus is a genus of shrubs, trees and climbers with approximately 150 species were distributed in tropical and sub-tropical regions of Asia [2]. The genus of Mallotus belongs to the Malphighiales order, the Euphorbiaceae family, Acalyphoideae subfamily, Acalypeae pro parte and Rotterinae subtribe [3]. Research on Mallotus species revealed that this genus were very rich with active 
compounds such as flavonoids, phenolic compounds, terpenoids and phloroglucinol derivatives [5]. Moreover, the pharmaceutical research has found that some of chemical constituents of Mallotus have the capability to possess several biological activities such as antioxidant, anti-inflammatory, antimicrobial, antiviral, cytotoxic and antitumor activities [3]. Therefore, the outcomes from this study will improve and enhance the application of natural product in the development of drug discovery.

Some species of the genus of Mallotus in Malaysia are used as traditional medicines. The roots of M. paniculatus are boiled and drunk after child birth, the leaves of M. macrostachyus are used as an antidote against snake poison whereas the roots and fruits of M. barbatus are used against muscle stiffness [2]. Mallotus leucodermis Hook f., is also commonly known as "balik angin bopeng" in Malaysia, is used to treat skin complaints [4]. In this study, two compounds namely bergenin (1) and epicatechin (2) have been isolated from the stem bark of Mallotus leucodermis. The structure elucidation of these two compounds will be discussed according to NMR (1D and 2D) analysis and also by the comparison with the literature data.

\section{Chemicals and plant materials}

\section{Materials and Methods}

The industrial grade solvent was used for extraction of sample while the analytical grade solvents such as acetone, chloroform $\left(\mathrm{CHCl}_{3}\right)$, ethyl acetate $(\mathrm{Ea})$, hexane $(\mathrm{Hex})$, and methanol $(\mathrm{MeOH})$, were used in the isolation and purification of compounds. The stem bark of M. leucodermis Hook f., was collected from Kuala Keniam, Pahang National Park.

\section{Extraction procedure}

Air dried and pulverized stem bark of M. leucodermis $(1.3 \mathrm{~kg}$ ) was successively extracted with $95 \%$ acetone for 72 hours at room temperature. The extract was then filtered and evaporated to dryness under reduced pressure using rotary evaporator. The maceration was repeated three times to obtain optimum yield of crude extract. The crude extract ( $124.6 \mathrm{~g}$ ) was subjected to removal of tannin by using diethyl ether yielded less tannin crude extract $67.8 \mathrm{~g}$.

\section{Fractionation and isolation}

The crude extract was subjected to vacuum liquid chromatography (VLC) over silica gel eluted with hexane: ethyl acetate (3:7 - 1:9) and $\mathrm{CHCl}_{3}$ : acetone (7:3 - 3:7) to yield several fractions. All fractions were spotted on thin layer chromatography (TLC) plate and the similar patterns of separation were combined together into six fractions (F1 F6). The last fraction from VLC was further purified by repeated washing using acetone and methanol to give white crystal ML1 (0.66 g). Fraction $3(800 \mathrm{mg})$ was then subjected to radial chromatography on silica coated plate with $\mathrm{CHCl}_{3}$ : acetone $(9: 1-5: 5)$ to give seven subfractions. Subfraction 7 (F3.7) was further purified by radial chromatography (RC) using $\mathrm{CHCl}_{3}$ : acetone (8:2, 6:4, 5:5) and washing method to give ML2 (17 mg).

\section{Structure elucidation}

The pure compounds were identified by using NMR spectroscopy on a Bruker AC 300 instrument, UV-Vis spectrophotometer, Infra-red, FTIR and gas chromatography - mass spectrometry, GC-MS. The spectra were measured on the spectrometers. Structures identified after analysis of the data obtained from spectra.

\section{Structural elucidation of isolated compounds}

\section{Results and Discussion}

The isolated compounds were characterized and identified via 1D and 2D NMR spectroscopy and by comparison with literature data. The structures of these pure compounds were shown in Figure 1.

The pure compound ML1 is a white crystals, isolated from VLC and recrystallized in methanol. Compound ML1 gave a $[\mathrm{M}]^{+}$at $\mathrm{m} / \mathrm{z} 328$ in the EI-mass spectrum, which corresponds to the molecular formula $\mathrm{C}_{14} \mathrm{H}_{16} \mathrm{O}_{9}$. The melting point for this compound is consistent with the reported melting point of bergenin which is $236-238{ }^{\circ} \mathrm{C}$ [6]. The ${ }^{1} \mathrm{H}$ NMR spectrum showed a signal for an aromatic proton at $\delta_{\mathrm{H}} 6.99(1 \mathrm{H}, \mathrm{s})$ and a signal for methoxy protons at $\delta_{\mathrm{H}} 3.77(3 \mathrm{H}, \mathrm{s})$. The ${ }^{13} \mathrm{C}$ APT spectrum showed the total of 14 resonances representing 14 carbons. The carbonyl group signal appeared at downfield region, $\delta 163.8$ (C-2) whereas the signal for methoxy carbon appeared at $\delta 60.3$ $(\mathrm{C}-15)$. The methylene carbon (C-16) showed a signal at $\delta_{\mathrm{C}} 61.5$ while the five peaks of methine carbons in glucose 
ring appeared at $\delta_{\mathrm{C}} 71.3(\mathrm{C}-12), 72.5(\mathrm{C}-9), 74.1(\mathrm{C}-13), 80.2(\mathrm{C}-14)$ and $82.2(\mathrm{C}-11)$. Table 1 summarised the ${ }^{1} \mathrm{H}$ and ${ }^{13} \mathrm{C}$ NMR data for ML1 in comparison with the literature data. Based on the spectral data and comparison with literature [7] and [8], ML1 was determined to be a bergenin.

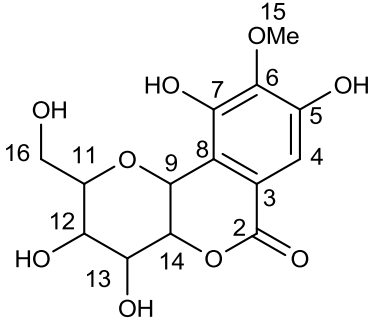

1<smiles>C[C@@H]1Cc2c(O)cc(O)cc2O[C@H](c2ccc(O)c(O)c2)[C@@H]1O</smiles>

2

Figure 1. Structure of isolated compounds (1) bergenin and (2) epicatechin

Bergenin is a colourless crystalline polyphenol, which contains five hydroxyl groups that played an important role in its pharmacological activity [5]. This compound is reported in literature to exhibit various biological activities such as antifungal, antiulcer, burn wound healing effects and also immunomodulatory [6]. Bergenin was previously isolated from Mallotus philippinensis, Mallotus japonicus, and Bergenial crassifolia [5].

Table 1. The comparison of ${ }^{1} \mathrm{H}$ and ${ }^{13} \mathrm{C}$ NMR for ML1 with the literature data

\begin{tabular}{lllcc}
\hline No. & $\boldsymbol{\delta} \mathbf{H}$ & $* \boldsymbol{\delta} \mathbf{H}$ & $\boldsymbol{\delta} \mathbf{C}$ & $* * \boldsymbol{\delta} \mathbf{C}$ \\
\hline 1 & - & - & - & - \\
2 & - & - & 163.8 & 164.6 \\
3 & - & - & 118.5 & 118.2 \\
4 & $6.99(1 \mathrm{H}, \mathrm{s})$ & $6.99(1 \mathrm{H}, \mathrm{s})$ & 109.9 & 109.9 \\
5 & $9.76(1-\mathrm{OH}, \mathrm{s})$ & $9.75(1-\mathrm{OH}, \mathrm{s})$ & 151.4 & 151.1 \\
6 & - & - & 141.0 & 141.1 \\
7 & $8.45(1-\mathrm{OH}, \mathrm{s})$ & $8.45(1-\mathrm{OH}, \mathrm{s})$ & 148.5 & 148.2 \\
8 & - & - & 116.4 & 116.1 \\
9 & $4.98(1 \mathrm{H}, \mathrm{d}, \mathrm{J}=10.8 \mathrm{~Hz})$ & $4.99(1 \mathrm{H}, \mathrm{d}, \mathrm{J}=10.5 \mathrm{~Hz})$ & 72.5 & 73.1 \\
10 & - & - & - & - \\
11 & $3.58(1 \mathrm{H}, \mathrm{t}, \mathrm{J}=8.1 \mathrm{~Hz})$ & $3.57(1 \mathrm{H}, \mathrm{t}, \mathrm{J}=8.8 \mathrm{~Hz})$ & 82.2 & 81.9 \\
12 & $3.22(1 \mathrm{H}, \mathrm{ddd}, \mathrm{J}=8.1,5.1 \mathrm{~Hz})$ & $3.20(1 \mathrm{H}, \mathrm{ddd}, \mathrm{J}=8.8,6.6 \mathrm{~Hz})$ & 71.1 & 70.7 \\
13 & $3.67(1 \mathrm{H}, \mathrm{ddd}, \mathrm{J}=5.4,3.3,5.4 \mathrm{~Hz})$ & $3.65(1 \mathrm{H}, \mathrm{ddd}, \mathrm{J}=8.8,5.6,5.6 \mathrm{~Hz})$ & 74.1 & 74.4 \\
14 & $4.00(1 \mathrm{H}, \mathrm{dd}, \mathrm{J}=10.2,9.6 \mathrm{~Hz})$ & $4.00(1 \mathrm{H}, \mathrm{dd}, \mathrm{J}=10,9.6 \mathrm{~Hz})$ & 80.2 & 80.2 \\
15 & $3.77(3 \mathrm{H}, \mathrm{s})$ & $3.78(3 \mathrm{H}, \mathrm{s})$ & 60.3 & 59.8 \\
16 & $3.83(1 \mathrm{H}, \mathrm{dd}, \mathrm{J}=10.8 \mathrm{~Hz})$ & $3.84(1 \mathrm{H}, \mathrm{dd}, \mathrm{J}=11.6,4.4 \mathrm{~Hz})$ & 61.5 & 61.5 \\
\hline
\end{tabular}

$*{ }^{1} \mathrm{H}\left(400 \mathrm{MHz}, \mathrm{DMSO}_{6}\right)$ [7]

$* *{ }^{13} \mathrm{C}\left(500 \mathrm{MHz}, \mathrm{CD}_{3} \mathrm{OD}-\mathrm{d}_{4}\right)[8]$ 
The pure compound ML2 was obtained as yellow powder, after several purification using $\mathrm{RC}$ eluted with $\mathrm{CHCl}_{3}$ : acetone $(9: 1-5: 5)$. Compound ML2 gave a $[\mathrm{M}]^{+}$at $\mathrm{m} / \mathrm{z} 313.2$ in the EIMS, corresponding to the molecular formula $\mathrm{C}_{15} \mathrm{H}_{14} \mathrm{O}_{6}$. The melting point obtained $224-226{ }^{\circ} \mathrm{C}$ which is acceptable with the literature melting point of epicatechin [9]. The $1 \mathrm{H}$ NMR spectrum showed a broad singlet peak at $\delta_{\mathrm{H}} 4.88(1 \mathrm{H}, \mathrm{s}, \mathrm{H}-2)$ which indicate a cisorientation between $\mathrm{H}-2$ and $\mathrm{H}-3$. An ABD system was observed at region by protons at $\delta_{\mathrm{H}} 6.81\left(\mathrm{~d}_{\mathrm{o}}\right), 6.83\left(\mathrm{~d}_{\mathrm{m}}\right)$ and $7.06(\mathrm{dd})$. The spectrum also revealed two doublets at $\delta_{\mathrm{H}} 6.04(\mathrm{H}-8)$ and $\delta_{\mathrm{H}} 5.93(\mathrm{H}-6)$ which were indicated as proton with meta-subtitution in ring A. The ${ }^{13} \mathrm{C}$ APT spectrum showed the total of 15 resonances representing 15 carbons. The methylene carbon $(\mathrm{C}-4)$ showed a signal at very upfield region at $\delta_{\mathrm{C}} 28.1$ whereas the signal at $\delta_{\mathrm{C}} 78.5$ represents $\mathrm{C}-2$. The total of seven signals of quarternary carbons at $\delta_{\mathrm{C}} 157.0,157.2,156.6,99.6,131.7,144.9$ and 145.1 representing as C-5, C-7, C-9, C-10, C-1', C-3', and C-4', respectively.

Table 2 summarized the ${ }^{1} \mathrm{H}$ and ${ }^{13} \mathrm{C}$ NMR data for ML2 in comparison with the literature data. Based on the spectral data and comparison with literature [10], ML2 was confirmed to be an epicatechin. Epicatechin is a flavan-3-ol, a type of natural phenol and antioxidant. It belongs to the family of flavonoids. This major flavanol in food is known to possess antioxidant, antiulcer and anti-inflammatory [7].

Table 2. The comparison of ${ }^{1} \mathrm{H}$ and ${ }^{13} \mathrm{C}$ NMR for ML2 with the literature data

\begin{tabular}{lllcc}
\hline No. & $\boldsymbol{\delta} \mathbf{H}$ & $* \boldsymbol{\delta} \mathbf{H}$ & $\boldsymbol{\delta} \mathbf{C}$ & $* \boldsymbol{\delta} \mathbf{C}$ \\
\hline 1 & - & - & - & - \\
2 & $4.88(1 \mathrm{H}, \mathrm{s})$ & $4.88(1 \mathrm{H}, \mathrm{s})$ & 78.5 & 79.1 \\
3 & $4.21(1 \mathrm{H}, \mathrm{m})$ & $4.24(1 \mathrm{H}, \mathrm{m})$ & 66.1 & 66.6 \\
$4 \beta$ & $2.72(1 \mathrm{H}, \mathrm{dd}, \mathrm{J}=16.5,3.6 \mathrm{~Hz})$ & $2.72(1 \mathrm{H}, \mathrm{dd}, \mathrm{J}=16.7,3.5 \mathrm{~Hz})$ & 28.1 & 28.5 \\
$4 \alpha$ & $2.89(1 \mathrm{H}, \mathrm{dd}, \mathrm{J}=16.5,4.5 \mathrm{~Hz})$ & $2.87(1 \mathrm{H}, \mathrm{dd}, \mathrm{J}=16.7,4.5 \mathrm{~Hz})$ & & \\
5 & - & - & 156.7 & 157.0 \\
6 & $5.93(1 \mathrm{H}, \mathrm{d}, \mathrm{J}=1.5 \mathrm{~Hz})$ & $5.96(1 \mathrm{H}, \mathrm{d}, \mathrm{J}=2.3 \mathrm{~Hz})$ & 95.3 & 96.1 \\
7 & - & - & 156.7 & 157.2 \\
8 & $6.04(1 \mathrm{H}, \mathrm{d}, \mathrm{J}=1.5 \mathrm{~Hz})$ & $6.06(1 \mathrm{H}, \mathrm{d}, \mathrm{J}=2.3 \mathrm{~Hz})$ & 94.8 & 95.4 \\
9 & - & - & 156.2 & 156.6 \\
10 & - & - & 98.9 & 99.6 \\
1 & & - & 131.3 & 131.7 \\
2 & $7.06(1 \mathrm{H}, \mathrm{s})$ & $7.05(1 \mathrm{H}, \mathrm{s})$ & 114.4 & 115.1 \\
3 & - & - & 144.5 & 144.9 \\
4 & - & - & 145.6 & 145.1 \\
5 & & $6.83(2 \mathrm{H}, \mathrm{m})$ & 114.6 & 115.1 \\
6 & $6.83(2 \mathrm{H}, \mathrm{m})$ & 118.4 & 119.1 \\
\hline
\end{tabular}

$*\left(300 \mathrm{MHz}\right.$, acetone- $\left.\mathrm{d}_{6}\right)[10]$.

\section{Spectroscopic data}

Bergenin (1): $\mathrm{C}_{14} \mathrm{H}_{16} \mathrm{O}_{9}$, white crystals (0.66 g), m.p 236-238 ${ }^{\circ} \mathrm{C}$. ESI-MS (positive mode) $\mathrm{m} / \mathrm{z} 328.0[\mathrm{M}+\mathrm{Na}]^{+} .{ }^{1} \mathrm{H}$ NMR (DMSO-d 6 , $300 \mathrm{MHz}) \delta: 3.22(1 \mathrm{H}, \mathrm{ddd}, \mathrm{J}=8.1 \mathrm{~Hz}, 5.1 \mathrm{~Hz}, \mathrm{H}-12), 3.58$ (1H, t, J=8.1 Hz, H-11), 3.67 (1H, ddd, J=5.4Hz, 3.3Hz, 5.4Hz, H-13), $3.77\left(3 \mathrm{H}, \mathrm{s}, \mathrm{OCH}_{3}\right), 3.83(1 \mathrm{H}, \mathrm{dd}, \mathrm{J}=10.8 \mathrm{~Hz}, \mathrm{H}-16), 4.00(1 \mathrm{H}, \mathrm{dd}, \mathrm{J}=10.2 \mathrm{~Hz}$, 9.6Hz, H-14), 4.98 (1H, d, J=10.5Hz, H-9), 6.99 (1H, s, H-4). 13C NMR (DMSO-d, $300 \mathrm{MHz}) \delta: 163.8(\mathrm{C}-2)$, 151.4 (C-5), 148.5 (C-7), 141.0 (C-6), 118.5 (C-3), 116.4 (C-8), 109.9 (C-4), 82.2 (C-11), 80.2 (C-14), 74.1 (C-13), 72.5 (C-9), 71,1 (C-12), 60.3 (C-15), 61.5 (C-16). 
Epicatechin (2): $\mathrm{C}_{15} \mathrm{H}_{14} \mathrm{O}_{6}$, yellowish powder (17 mg), m.p. 224-226 ${ }^{\circ} \mathrm{C}$. ESI-MS (positive mode) $\mathrm{m} / \mathrm{z} 313.2$ $[\mathrm{M}+\mathrm{Na}]^{+}, 291.2[\mathrm{M}+\mathrm{H}]^{+} .{ }^{1} \mathrm{H}$ NMR (Acetone- $\left.{ }_{6}, 300 \mathrm{MHz}\right) \delta: 2.72(1 \mathrm{H}, \mathrm{dd}, \mathrm{J}=16.5 \mathrm{~Hz}, 3.6 \mathrm{~Hz}, \mathrm{H}-4 \beta), 2.89(1 \mathrm{H}, \mathrm{dd}$, $\mathrm{J}=16.5 \mathrm{~Hz}, 4.5 \mathrm{~Hz}, \mathrm{H}-4 \alpha), 4.21(1 \mathrm{H}, \mathrm{m}, \mathrm{H}-3), 4.88(1 \mathrm{H}, \mathrm{s}, \mathrm{H}-2), 5.93(1 \mathrm{H}, \mathrm{d}, \mathrm{J}=1.2 \mathrm{~Hz}, \mathrm{H}-6), 6.04(1 \mathrm{H}, \mathrm{d}, \mathrm{J}=1.5$ $\mathrm{Hz}, \mathrm{H}-8), 6.83\left(2 \mathrm{H}, \mathrm{m}, \mathrm{H}-5^{\prime}, \mathrm{H}-6^{\prime}\right), 7.06\left(1 \mathrm{H}, \mathrm{s}, \mathrm{H}-2^{\prime}\right) .{ }^{13} \mathrm{C}$ NMR (Acetone-d 6 , 300MHz) $\delta: 28.5$ (C-4), 66.6 (C-3), 79.1 (C-2), 95.4 (C-8), 96.1 (C-7), 99.6 (C-10), 115.1 (C-2'), 115.5 (C-5'), 119.1 (C-6'), 131.2 (C-1'), 144.9 (C-3'), 145 (C-4'), 156.6 (C-9), 157.0 (C-5), 157.2 (C-7).

\section{Conclusion}

The isolation and identification of bergenin (1) and epicatechin (2) from the stem bark of Mallotus leucodermis Hook f., was the first ever to be reported from this plants. These compounds were elucidated based on spectroscopic analysis (UV-Vis, Infra-Red, Mass Spectra and Nuclear Magnetic Resonance) as well as comparison with literatures.

\section{Acknowledgement}

The authors would like to thank Professor Dr Mohd Nazip Suratman, the botanist and lecturer from Universiti Teknologi MARA Shah Alam for his contribution in identifying the plant species. The authors are also grateful to Faculty of Applied Sciences (UiTM) for providing lab facility during this study.

\section{References}

1. Thakur, H. A. and Patil, D. A. (2011). Taxonomic and phylogenetic assessment of the Euphorbiaceae: A review. Journal of Experimental Sciences, 2 (3):37 - 46.

2. Sierra, S. E. C., Welzen, P.C. and Slik, J. W. F. (2005). A taxonomic revision of Mallotus section philippinensis (former section Rottlera-Euphorbiaceae) in Malesia and Thailand. Blumea, $50: 221$ - 248.

3. Riviere C., Hong V. N. T., Hong Q. T., Chataigne G., Hoai N. N., Dejaegher B., Tistaert C., Kim T. N. T., Heyden, Y. V., Van, M. C. and Quetin-Leclercq, J. (2010). Mallotus species from Vietnamese mountainous areas: phytochemistry and pharmacological activities. Phytochemical Review, 9: 217 -253.

4. Faridah, H. and Nurulhuda, H. (1999). The use of medicinal plant species by the temuan tribe of Ayer Hitam Forest, Selangor, Peninsular Malaysia. Pertanika Journal of Tropical Agriculture Science, 22 (2):85 - 94.

5. Patel, D., Patel, K., Kumar, R., Gadewar, M., and Tahilyani, V. (2012). Pharmacological and analytical aspects of bergenin: A concise report. Asian Pacific Journal of Tropical Disease, 2 (2): 163 - 167.

6. Nasser, J. A., Yaacob, W. A., Din, L. B., Yamin, B. M, and Latip, J. (2009). Isolation of atranorin, bergenin and goniothalamin from Hopea Sangal. Journal of Engineering and Applied Sciences, 4 (1): 92 - 95.

7. Jimenez, R., Duarte, J., and Perez-vizcaino, F. (2012). Epicatechin: Endothelia funtion and blood pressure. Journal of Agriculture and Food Chemistry, 60(36): 8823 - 8830.

8. Nunomura, R. C. S., Oliveira, V. G. and Nunomura, S. M. (2009). Characterization of bergenin in Endopleura uchi bark and its anti-inflammatory activity. Journal of Brazilian Chemical Society, 20 (6): 1060 - 1064.

9. Wei, X. H., Yang, S. J., Liang, N., Hu, D.Y., Jin, L. H., Xue, W. and Yang, S., (2013). Chemical constituents of Caesalpinia decapetala (Roth) Alston. Molecules, 18 (1):1325 - 1336.

10. Lu, Y. and Foo, L.Y. (1999). The polyphenol constituents of grape pomace. Food Chemistry, 65: 1 - 8. 